Transport, and Professor R. L. Crocker, Botany School, University of Sydney, in whose Laboratories the work was carried out.

\section{REFERENCES}

Balazs, R. \& Richter, D. (1958a). Biochem. J. 68, 5 P. Balazs, R. \& Richter, D. (1958b). Biochem. J. 69, 57 P. Benesch, R. \& Benesch, R. E. (1945). Arch. Biochem. 19, 35.

Conn, E. E. \& Vennesland, B. (1951). J. biol. Chem. 192, 17.

Fromageot, C. (1951). In The Enzymes, vol. 2, pt. 1, p. 609. Ed. by Sumner, J. B. \& Myrbäck, K. New York: Academic Press Inc.

Hageman, R. H. \& Arnon, D. I. (1955). Arch. Biochem. Biophys. 55, 162.

Hatch, M. D. \& Turner, J. F. (1958). Biochem. J. 69, 495. Hatch, M. D. \& Turner, J. F. (1959). Biochem. J. 72, 524. Haugaard, N., Hess, M. E. \& Itskovitz, H. (1957). J. biol. Chem. 227, 605.
Labeyrie, F. (1949). Bull. Soc. Chim. biol., Paris, 31, 1624.

MacDonnell, L. R., Silva, R. B. \& Feeney, R. E. (1951). Arch. Biochem. Biophys. 32, 288.

Mandels, G. R. (1956). J. Bact. 72, 203.

Mapson, L. W. \& Goddard, D. R. (1951). Biochem. .J. 49, 592.

Neufeld, H. A., Green, L. F., Latterell, F. M. \& Weintraub, R. L. (1958). J. biol. Chem. 232, 1093.

Racker, E. (1955). J. biol. Chem. 217, 855.

Rapkine, L., Rapkine, S. M. \& Trpinac, P. (1939). C.R. Acad. Sci., Paris, 209, 253.

Romano, A. H. \& Nickerson, W. J. (1954). J. biol. Chem. 208, 409.

Turner, J. F. (1954). Nature, Lond., 174, 692.

Turner, J. F. (1957). Biochem. J. 67, 450.

Turner, J. F. \& Mapson, L. W. (1958). Nature, Lond., 181, 270.

Velick, S. F. (1953). J. biol. Chem. 203, 563.

Warburg, O. \& Christian, W. (1939). Biochem. Z. 303, 40.

Warburg, O. \& Christian, W. (1941). Biochem. Z. 310, 384.

Biochem. J. (1960) 75, 72

\title{
Lactic Dehydrogenase and Cytochrome $b_{2}$ of Baker's Yeast
}

\section{THE AMINO ACID COMPOSITION OF THE CRYSTALLINE ENZYME}

\author{
By C. A. APPLEBY* and R. K. MORTON† \\ Department of Biochemistry, University of Melbourne
}

AND D. H. SIMMONDS $\dagger$

Division of Protein Chemistry, Wool Textile Research Laboratories, C.S.I.R.O., Melbourne, Australia

(Received 28 July 1959)

Appleby \& Morton (1954, 1959a,b, 1960) have described the purification and crystallization of yeast lactic dehydrogenase, and the enzymic, chemical and physical properties of the crystalline chromoprotein, which was shown to be identical with cytochrome $b_{2}$. This paper describes the amino acid composition as determined qualitatively by paper chromatography and quantitatively with ion-exchange-resin columns. An account of this work was given to the Australian Biochemical Society in August, 1957 (Simmonds, Appleby \& Morton, $1957 a, b$; Morton, 1958).

\section{MATERIALS}

Yeast lactic dehydrogenase (cytochrome $\mathrm{b}_{2}$ ). The crystalline cytochrome was prepared as described by Appleby \& Morton $(1959 a)$. Unless otherwise stated, the material was

* Present address : Division of Plant Industry, C.S.I.R.O., Canberra.

$\dagger$ Present address: Department of Agricultural Chemistry, The Waite Agricultural Research Institute, University of Adelaide. recrystallized three times from a solution of the combined first crystals from a number of preparations.

Gelatin. The tyrosine-free protein was a gift from Davis Gelatine Co. Ltd., Sydney, N.S.W.

$\beta$-Lactoglobulin. Three-times crystallized material was a gift from Dr F. J. R. Hird.

Organic solvents. These were purified for chromatography by distillation at reduced pressure.

\section{EXPERIMENTAL AND RESULTS}

Amino acid composition by paper chromatography Approx. $3 \mathrm{mg}$. of once-crystallized enzyme was hydrolysed with $0.1 \mathrm{ml}$. of $5 \mathrm{~N}-\mathrm{HCl}$ in a sealed ampoule at $105^{\circ}$ for $20 \mathrm{hr}$. After removal of $\mathrm{HCl}$, the residue was dissolved in about $70 \mu \mathrm{l}$. of propan-2-ol (acidified with $\mathrm{HCl}$ ). Suitable portions $(4-10 \mu l$.) were applied to the appropriate grade of Whatman chromatography paper. The amino acids were separated by two-dimensional chromatography as described by Dent (1947). The ninhydrin-reactive compounds of the enzyme hydrolysate were identified by comparison with similar chromatograms of a reference mixture of known 
amino acids. The results were confirmed with twodimensional chromatography as described by Boissonnas (1950). The amino acids identified are shown in Table 1.

Attempts to detect tyrosine and histidine with the Pauly reagent (Dent, 1947) on papers developed in collidine-lutidine solvent (Dent, 1947) were unsuccessful. Because of the intense absorption due to nucleotides associated with the crystalline cytochrome (see Appleby \& Morton, 1959b, 1960), the spectrophotometric method of Beavan \& Holiday (1952) for estimation of tyrosine and tryptophan could not be used. Tyrosine was, however, detected by the following procedure. Approx. $2.5 \mathrm{mg}$. of twice-recrystallized cytochrome $b_{2}$ was hydrolysed with $5 \mathrm{~N}-\mathrm{HCl}$ as already described, the acid was removed, the residue was dissolved in water and the whole solution applied as a spot on Whatman no. 4 chromatographic paper. Reference spots of tyrosine and of hydrolysates of $\beta$-lactoglobulin and of gelatin were also applied. The chromatogram was developed in butanol-formic acid-water according to Acher \& Crocker (1952). The tyrosine was detected by the reaction with $\alpha$-nitroso- $\beta$-naphthol (see Acher \& Crocker, 1952). No tyrosine was detected in the gelatin.

Tryptophan. Tryptophan was estimated by the method of Spies \& Chambers (1949). $\beta$-Lactoglobulin, which contains $2.5 \%$ of tryptophan (Spies \& Chambers, 1949), was used as a standard. Portions of $\beta$-lactoglobulin (1-4 mg.) and of cytochrome $b_{2}(1.5 \mathrm{mg}$.) were dissolved in $5.8 \mathrm{ml}$. of $19 \mathrm{~N}-\mathrm{H}_{2} \mathrm{SO}_{4}$ at room temperature (approx. $20^{\circ}$ ). After $20 \mathrm{~min}$., approx. $18 \mathrm{mg}$. of $p$-dimethylaminobenzaldehyde was added to each tube and, after about $12 \mathrm{hr}$. at room temperature, $0.2 \mathrm{ml}$. of aq.
$0.014 \% \mathrm{NaNO}_{2}$. After an additional $30 \mathrm{~min}$. at room temperature, $E$ at $590 \mathrm{~m} \mu$ was determined with a Beckman spectrophotometer (model DU). It was found that the addition of haemin and of riboflavin phosphate to $\beta$-lactoglobulin before treatment caused no interference with the estimation of tryptophan. Hence it was concluded that these prosthetic groups (Appleby \& Morton, 1954; $1959 b$ ) did not interfere with the estimation of tryptophan (0.82\%; see Table 2$)$ in cytochrome $b_{2}$. It is not known whether the deoxyribose polynucleotide component (Morton, 1958; Appleby \& Morton, 1960) caused any interference in this estimation.

\section{Amino acid analysis by resin-column chromatography}

The cytochrome $b_{2}$ was weighed into tubes with B 19 standard ground-glass sockets, $0.5 \mathrm{ml}$. of constant-boiling $\mathrm{HCl}$ was added to each sample, a reflux condenser was fitted and hydrolysis was carried out on an oil bath at $110^{\circ}$. Duplicate samples of approx. $2 \mathrm{mg}$. each were used for the acidic and neutral amino acids, and of approx. $3.5 \mathrm{mg}$. each for the basic amino acids. One sample was hydrolysed for $20 \mathrm{hr}$. and the other for $70 \mathrm{hr}$. The hydrolysates were dried in vacuo over $\mathrm{P}_{2} \mathrm{O}_{5}$ and $\mathrm{KOH}$ at room temperature for about 3 days to remove $\mathrm{HCl}$, and the residues were then dissolved in a minimum of water and transferred quantitatively to the tops of columns of Dowex-50 resin used for analysis.

The amino acids were separated by ion-exchange chromatography (Moore \& Stein, 1951) and were estimated by the colorimetric procedure with ninhydrin as described by Moore \& Stein (1948). The apparatus used for collecting and dispensing

Table 1. Amino acids identified in a hydrolysate of cytochrome $\mathrm{b}_{2}$ by separation by paper chromatography

Once-crystallized cytochrome $b_{2}\left(3 \mathrm{mg}\right.$.) was hydrolysed with $5 \mathrm{~N}-\mathrm{HCl}$ at $105^{\circ}$ for $20 \mathrm{hr}$. in a sealed ampoule. After drying, the residue was dissolved in $70 \mu \mathrm{l}$. of propan-2-ol, acidified with $\mathrm{HCl}$ and 4-10 $\mu \mathrm{l}$. portions were applied to filter paper. Chromatographic procedures were carried out according to the authors quoted and as described in the text. For definition of the abbreviations used for amino acids see Biochem. J. (1953), 55, 5.

Solvent systems used to develop chromatogram
Reference
Dent (1947)

$\overbrace{\begin{array}{c}\text { First system } \\ \text { Water-saturated phenol }\end{array} \begin{array}{c}\text { Second system } \\ \text { Collidine-lutidine-water }\end{array}}$
Boissonnas (1950) (a) tert.-butyl alcohol
butan-2-one

\section{tert.-butyl alcohol methanol-water \\ Propan-2-ol-water}
(b) Phenol-water
Acher \& Crocker (1952) $\begin{gathered}\text { Butan-1-ol-formic acid- } \\ \text { water }\end{gathered}$

\section{Amino acids identified}
Intense spots: Ala, Asp, Glu, Gly, leucine group, * Val
Weaker spots: Arg, Cys, $†$ Lys, Ser, Thr
Ala, Asp, Gly and Ser, $\ddagger$ leucine group,* Thr, Val and two spots unidentified
Ala, Arg, Asp, Cys, $\dagger$ leucine group,* Lys
Tyr

* Leucine, isoleucine and norleucine are not separated by these procedures.

$\dagger$ Cystine was detected as cysteic acid.

$\ddagger$ Glycine and serine are not separated in this procedure. 
the portions of effluent from the columns has been described by Simmonds (1954) and by Simmonds \& Wood (1954). Because of the overlap between glutamic acid and proline, and the low colour yield of proline when treated with ninhydrin at $\mathrm{pH} 5 \cdot 0$, the effluent fractions were divided into two groups at the period when these acids were expected. One group of alternate tubes from the column was treated with ninhydrin at $\mathrm{pH} \mathbf{5 \cdot 0}$ for estimation of glutamic acid (Moore \& Stein, 1948) and the second group was treated with the ninhydrin reagent of Chinard (1952) for estimation of proline.

All of the commonly occurring amino acids of proteins except tryptophan and cystine are determined by these procedures. Tryptophan was therefore estimated separately as already described. As shown in Table 1, cystine was identified in the enzyme hydrolysate by paper chromatography, but methionine was not detected. Neither methionine nor any of its oxidation products was detected in the effluents from the ion-exchange column. Hence it has been assumed that all of the sulphur $(0.74 \%$; Appleby \& Morton, 1960) of the cytochrome occurs as cysteine and cystine, and the amount (expressed as $\frac{1}{2}$-cystine) was calculated accordingly. Table 2 shows the results for the 20 and $70 \mathrm{hr}$. hydrolysates, expressed as percentage (by wt.) of the dried material.

For amino acids other than serine there appeared to be little loss during hydrolysis, and the mean of the results for both hydrolysis periods was used as the best estimate (Table 2). Since the decomposition of serine during hydrolysis of proteins with $\mathrm{HCl}$ is well established (Rees, 1946; Hirs, 1954; Smith \& Stockell, 1954; Smith, Stockell \& Kimmel, 1954), the results for serine were linearly extrapolated to zero time to obtain the best estimate, as given in Table 2. Glutamic acid undergoes decomposition to pyrrolidonecarboxylic acid during chromatography on the resin columns and accordingly the correction factor (1.03) of Moore \& Stein (1951) was used to obtain the mean value for this amino acid (Table 2).

\section{DISCUSSION}

The qualitative (Table 1) and quantitative (Table 2) analyses are in substantial agreement. It is probable that the two unidentified amino acids detected on the chromatogram according to Boissonnas (1950) were histidine and phenylalanine, which were identified by resin-column chromatography (cf. Tables 1 and 2).

Thus methionine is either absent or present in very small amount, and it has been assumed that all of the sulphur of cytochrome $b_{2}$ occurs as cystine and cysteine. If present to the extent of $0 \cdot 2-0.3 \%$, methionine would have been detected by both column and paper chromatography. The loss of lactic-dehydrogenase activity caused by

Table 2. Amino acid analysis of crystalline cytochrome $\mathrm{b}_{2}$ by chromatography on ion-exchange resin

Four-times crystallized enzyme was hydrolysed in constant-boiling $\mathrm{HCl}$ at $110^{\circ}$ for 20 and $70 \mathrm{hr}$. as indicated. Amino acids of the hydrolysates were separated on a column of Dowex-50 resin and estimated as described in the text, except that cystine was estimated from the total sulphur content of the enzyme and tryptophan was determined according to Spies \& Chambers (1949). Results are expressed as percentage (by wt.) of the dried material.

\begin{tabular}{|c|c|c|c|c|}
\hline & Am & 10 acid content $(\%)$ & & \\
\hline & $20 \mathrm{hr}$. hydrolysate & $70 \mathrm{hr}$. hydrolysate & Mean & S.D. \\
\hline Alanine & $4 \cdot 42,4 \cdot 51$ & $4 \cdot 36,4 \cdot 33$ & $4 \cdot 40$ & 0.08 \\
\hline Amide & 1.59 & $1 \cdot 66$ & $1 \cdot 62$ & - \\
\hline Arginine & $4 \cdot 68$ & $4 \cdot 48$ & $4 \cdot 58$ & - \\
\hline Aspartic acid & $9 \cdot 90,10 \cdot 11$ & $9 \cdot 71,9 \cdot 84$ & $9 \cdot 89$ & $0 \cdot 17$ \\
\hline $\begin{array}{l}\frac{1}{2} \text {-Cystine } \\
\text { Glutamic acid }\end{array}$ & $10 \cdot 62,11 \cdot 28$ & $10 \cdot 68,10 \cdot 89$ & $\begin{array}{c}2 \cdot 77 \\
10.87 *\end{array}$ & $\overline{0.30}$ \\
\hline Glycine & $3 \cdot 54,4 \cdot 01$ & $3 \cdot 80,4 \cdot 15$ & $3 \cdot 88$ & $0 \cdot 23$ \\
\hline Histidine & 1.05 & $1 \cdot 35$ & $1 \cdot 20$ & - \\
\hline Isoleucine & $4 \cdot 86$ & $4 \cdot 49,4 \cdot 31$ & $4 \cdot 55$ & $0 \cdot 28$ \\
\hline Leucine & $9 \cdot 03$ & $8 \cdot 77,9 \cdot 32$ & $9 \cdot 04$ & $0 \cdot 26$ \\
\hline Lysine & $8 \cdot 46$ & $8 \cdot 06$ & $8 \cdot 26$ & 一 \\
\hline Methionine & - & - & $<0.3 \dagger$ & - \\
\hline Phenylalanine & $2 \cdot 98,2 \cdot 65$ & $2 \cdot 73,3 \cdot 20$ & $2 \cdot 89$ & $0 \cdot 24$ \\
\hline Proline & $4 \cdot 72,5 \cdot 00$ & $4 \cdot 48$ & $4 \cdot 73$ & $0 \cdot 26$ \\
\hline Serine & $3 \cdot 42,3 \cdot 29$ & $2 \cdot 62,3 \cdot 34$ & 3.51† & - \\
\hline Threonine & $3 \cdot 28,3 \cdot 25$ & $3 \cdot 20,3 \cdot 40$ & $3 \cdot 28$ & 0.08 \\
\hline Tryptophan & - & - & $0 \cdot 82$ & - \\
\hline Tyrosine & $3 \cdot 17,2 \cdot 92$ & $2 \cdot 87,3 \cdot 62$ & $\mathbf{3} \cdot 14$ & $0 \cdot 33$ \\
\hline Valine & $6 \cdot 34$ & $6 \cdot 10,6 \cdot 03$ & $6 \cdot 16$ & $0 \cdot 16$ \\
\hline
\end{tabular}

* Values are corrected for formation of pyrrolidonecarboxylic acid.

$\dagger$ Not detected in column effluent.

$\$$ Value was obtained by extrapolation of results to zero time of hydrolysis. 
oxidizing agents (Appleby \& Morton, 1959b) and the inhibition by $p$-chloromercuribenzoate (Appleby $\&$ Morton, $1954,1959 b$ ) indicate that cysteine is present.

Table 3 shows the amino acid nitrogen as a percentage of the total nitrogen, and the residue weight of each amino acid as a percentage of the dry weight of the enzyme. Crystalline cytochrome $b_{2}$ contains $15 \cdot 2 \pm 0 \cdot 4 \%$ of nitrogen and approx. $14.2 \%$ of amino acid nitrogen (Appleby \& Morton, 1960). The amino acids (Table 3) represent $84 \%$ of the total nitrogen and approx. $91 \%$ of the amino acid nitrogen. However, only $74 \%$ of the total weight is accounted for by amino acids (Table 3). Crystalline cytochrome $b_{2}$ contains approx. $6 \%$ of a deoxyribose polynucleotide, approx. $0.8 \%$ of protohaem and approx. $0.9 \%$ of riboflavin phosphate (Appleby \& Morton, 1954, 1959b, 1960). Thus these results account for about $81 \%$ of the dry weight of the enzyme. The cause of the discrepancy between the recoveries, based on nitrogen and dry-weight estimations, is not known.

Table 3 shows the number of residues of each amino acid $/ 10^{4} \mathrm{~g}$. of protein and the number of residues/mole of enzyme-bound haem. Crystalline cytochrome $b_{2}$ has a weight of about $80000 \mathrm{~g}$./mole
Table 3. Amino acid composition of crystalline cytochrome $\mathrm{b}_{2}$ (yeast lactic dehydrogenase)

Values are derived from the results given in Table 2.

\begin{tabular}{|c|c|c|c|c|}
\hline & $\begin{array}{l}\text { Amino } \\
\text { acid } N \\
\text { as } \% \text { of } \\
\text { total } N\end{array}$ & $\begin{array}{c}\text { Residue } \\
\text { wt. as } \\
\% \text { of } \\
\text { dry wt. }\end{array}$ & $\begin{array}{l}\text { Residues/ } \\
10^{4} \mathrm{~g} \cdot \text { of } \\
\text { enzyme }\end{array}$ & $\begin{array}{c}\text { Residues/ } \\
\text { mole of } \\
\text { haem }\end{array}$ \\
\hline Alanine & $4 \cdot 55$ & $3 \cdot 51$ & $4 \cdot 94$ & $39 \cdot 5$ \\
\hline Amide & $9 \cdot 33$ & $1 \cdot 62$ & $10 \cdot 12$ & $81 \cdot 0$ \\
\hline Arginine & $9 \cdot 70$ & $4 \cdot 11$ & $2 \cdot 63$ & $21 \cdot 0$ \\
\hline Aspartic acid & $6 \cdot 85$ & $8 \cdot 55$ & $7 \cdot 44$ & $59 \cdot 5$ \\
\hline 1-Cystine & $2 \cdot 12$ & $2 \cdot 35$ & $2 \cdot 31$ & $18 \cdot 5$ \\
\hline Glutamic acid & $6 \cdot 81$ & $9 \cdot 54$ & $7 \cdot 39$ & $59 \cdot 1$ \\
\hline Glycine & $4 \cdot 77$ & $2 \cdot 95$ & $5 \cdot 17$ & $41 \cdot 4$ \\
\hline Histidine & $2 \cdot 14$ & 1.06 & 0.77 & $6 \cdot 2$ \\
\hline Isoleucine & $3 \cdot 20$ & 3.92 & $3 \cdot 47$ & $27 \cdot 8$ \\
\hline Leucine & $6 \cdot 35$ & $\mathbf{7 \cdot 8 0}$ & $6 \cdot 90$ & $55 \cdot 2$ \\
\hline Lysine & $10 \cdot 42$ & $7 \cdot 24$ & $5 \cdot 66$ & $45 \cdot 7$ \\
\hline Methionine* & 一 & - & 0 & 0 \\
\hline Phenylalanine & $1 \cdot 61$ & $\mathbf{2 \cdot 5 7}$ & $1 \cdot 75$ & $14 \cdot 0$ \\
\hline Proline & $3 \cdot 79$ & 3.99 & $4 \cdot 11$ & $32 \cdot 9$ \\
\hline Serine & $3 \cdot 08$ & $2 \cdot 91$ & $3 \cdot 31$ & $26 \cdot 5$ \\
\hline Threonine & $2 \cdot 52$ & $\mathbf{2 \cdot 7 8}$ & $2 \cdot 76$ & $22 \cdot 1$ \\
\hline Tryptophan & $0 \cdot 79$ & $0 \cdot 80$ & $0 \cdot 43$ & $3 \cdot 4$ \\
\hline Tyrosine & $1 \cdot 60$ & $2 \cdot 83$ & $1 \cdot 73$ & $13 \cdot 8$ \\
\hline Valine & $4 \cdot 85$ & $5 \cdot 21$ & $5 \cdot 26$ & $42 \cdot 1$ \\
\hline
\end{tabular}

* Not detected either in column effluent or by paper chromatography (cf. Table 1 and text).

Table 4. Comparative amino acid compositions of cytochrome $\mathrm{b}_{2}$ and some other proteins

Amino acid composition is expressed as g. of amino acid/100 g. of protein. Values for cytochrome $b_{2}$ have been calculated for the flavohaemoprotein, free of polynucleotide (cf. Appleby \& Morton, 1960).

\begin{tabular}{|c|c|c|c|c|c|}
\hline Enzyme & $\cdots$ & $\begin{array}{l}\text { Yeast alcohol } \\
\text { dehydrogenase }\end{array}$ & Pig-heart diaphorase & $\begin{array}{l}\text { Yeast cytochrome } b_{2} \\
\text { (lactic dehydrogenase) }\end{array}$ & Yeast cytochrome $c$ \\
\hline Type of protein & $\ldots$ & $\begin{array}{l}\text { Diphosphopyridine } \\
\text { nucleotide-linked } \\
\text { protein }\end{array}$ & Flavoprotein & Flavohaemoprotein & Haemoprotein \\
\hline Reference & $\cdots$ & Lange (1956) & Rees \& Savage (1958) & This paper & Nunnikhoven (1958) \\
\hline $\begin{array}{l}\text { Alanine } \\
\text { Amide } \\
\text { Arginine } \\
\text { Aspartic acid } \\
\text { 1-Cystine } \\
\text { Glutamic acid } \\
\text { Glycine } \\
\text { Histidine } \\
\text { Isoleucine } \\
\text { Leucine } \\
\text { Lysine } \\
\text { Methionine } \\
\text { Phenylalanine } \\
\text { Proline } \\
\text { Serine } \\
\text { Threonine } \\
\text { Tryptophan } \\
\text { Tyrosine } \\
\text { Valine }\end{array}$ & & $\begin{array}{l}6 \cdot 6 \\
4 \cdot 9 \\
8 \cdot 6 \\
4 \cdot 4 \\
6 \cdot 6 \\
5 \cdot 9 \\
2 \cdot 5 \\
7 \cdot 0 \\
7 \cdot 1 \\
7 \cdot 8 \\
5 \cdot 1 \\
5 \cdot 7 \\
4 \cdot 8 \\
5 \cdot 8 \\
6 \cdot 6 \\
1 \cdot 7 \\
6 \cdot 0 \\
6 \cdot 9\end{array}$ & 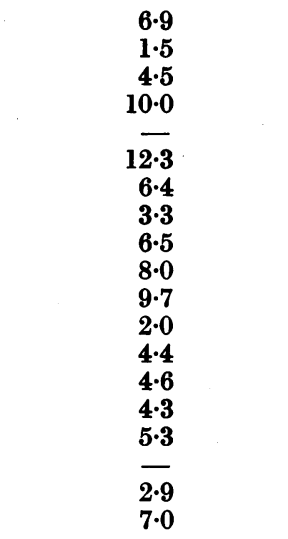 & $\begin{array}{r}4 \cdot 6 \\
1 \cdot 7 \\
4 \cdot 8 \\
10 \cdot 4 \\
2 \cdot 9 \\
11 \cdot 5 \\
4 \cdot 1 \\
1 \cdot 3 \\
4 \cdot 8 \\
9 \cdot 5 \\
8 \cdot 7 \\
<0 \cdot 3 \\
3 \cdot 1 \\
4 \cdot 9 \\
3 \cdot 7 \\
3 \cdot 5 \\
0 \cdot 9 \\
3 \cdot 3 \\
6 \cdot 5\end{array}$ & $\begin{array}{r}4 \cdot 5 \\
1 \cdot 6 \\
3 \cdot 7 \\
11 \cdot 0 \\
1 \cdot 8 \\
10 \cdot 0 \\
5 \cdot 8 \\
4 \cdot 0 \\
3 \cdot 8 \\
6 \cdot 8 \\
16 \cdot 6 \\
2 \cdot 1 \\
4 \cdot 4 \\
3 \cdot 6 \\
3 \cdot 3 \\
7 \cdot 2 \\
1 \cdot 6 \\
5 \cdot 7 \\
2 \cdot 6\end{array}$ \\
\hline Mol. wt. (g.) & & $150000^{*}$ & $81000 \dagger$ & $75000 \ddagger$ & $13200 \S$ \\
\hline
\end{tabular}

* Hayes \& Velick (1954).

+ Savage (1957).

$\ddagger$ Minimum weight (g.)/mole.

$\S$ Based on dry weight; $11800 \mathrm{~g} . /$ mole based on total protein (Nunnikhoven, 1958). 
of haem (Appleby \& Morton, 1959 b). Table 3 shows that alanine, aspartic acid, $\frac{1}{2}$-cystine and serine would occur with exactly 0.5 of a residue/mole of haem, but no amino acids would occur with 0.5 of a residue/mole if there are two haem groups/mole of enzyme, as seems likely (Appleby \& Morton, 1960).

As yet, cytochrome $c$ (de Barbieri \& Scevola, 1955; Ehrenberg \& Theorell, 1955; Nunnikhoven, 1958; Leaf, Gillies \& Pirie, 1958) is the only cytochrome other than cytochrome $b_{2}$ for which the amino acid composition has been determined (see Morton, 1958). Table 4 shows the amino acid composition of cytochrome $b_{2}$ (yeast lactic dehydrogenase) expressed as g. of amino acid/100 g. of polynucleotide-free enzyme, on which basis this flavohaemoprotein may be directly compared with yeast alcohol dehydrogenase, yeast cytochrome $c$ and pig-heart diaphorase (Table 4). These represent a typical diphosphopyridine nucleotide-linked dehydrogenase, a haemoprotein and a flavoprotein respectively. All are directly concerned in hydrogen (or electron) transport. Table 4 shows that the flavohaemoprotein (cytochrome $b_{2}$ ) shows a general similarity in composition to each of the other proteins and especially to diaphorase, the only flavoprotein for which the amino acid composition is available. The comparative amino acid composition of cytochrome $b_{2}$ and cytochrome $c$ has been discussed elsewhere by Morton (1958). Whereas the amino acid compositions of the proteins shown in Table 4 are rather similar, they differ from the compositions of other enzymes such as catalase, pepsin and $\alpha$-amylase (see Dixon \& Webb, 1958). It is possible therefore that certain features of the amino acid patterns are related to their enzymic functions.

Cytochrome $b_{2}$ thus shows no unique features of amino acid composition, except for the apparent absence (less than $0.3 \%$ ) of methionine. Most proteins and almost all enzymes so far studied contain between 0.5 and $5.0 \%$ of methionine. The apparent absence of methionine in cytochrome $b_{2}$ supports the conclusion based on other studies (Appleby \& Morton, 1954, 1959a, b, 1960) that the crystalline material contains only one protein.

\section{SUMMARY}

1. Crystalline cytochrome $b_{2}$ was hydrolysed with $5 \mathrm{~N}$-hydrochloric acid at $105^{\circ}$ for $20 \mathrm{hr}$. and the liberated amino acids were separated by paper chromatography according to Dent (1947) and Boissonnas (1950). Most of the commonly occurring amino acids, except methionine, were detected.

2. The amino acids in hydrolysates obtained after 20 and $70 \mathrm{hr}$. at $110^{\circ}$ with constant-boiling hydrogen chloride solution were separated on a column of Dowex-50 according to Moore \& Stein (1951) and estimated by the colour developed with ninhydrin. Methionine was not detected.

3. Comparison of the amino acid composition of cytochrome $b_{2}$, yeast cytochrome $c$, yeast alcohol dehydrogenase and pig-heart diaphorase shows considerable similarity between these several proteins.

We wish to thank Barrett's Food Company Ltd., Melbourne, for the generous gift of dried yeast and the Division of Plant Industry, C.S.I.R.O., for financial support for this investigation.

\section{REFERENCES}

Acher, R. \& Crocker, C. (1952). Biochim. biophys. Acta, 9, 704.

Appleby, C. A. \& Morton, R. K. (1954). Nature, Lond., 173, 749.

Appleby, C. A. \& Morton, R. K. (1959a). Biochem. J. 71, 492.

Appleby, C. A. \& Morton, R. K. (1959b). Biochem. J. 73, 539.

Appleby, C. A. \& Morton, R. K. (1960). Biochem. J. (in the Press).

Beavan, G. H. \& Holiday, E. R. (1952). Advanc. Protein Chem. 7, 319.

Boissonnas, R. A. (1950). Helv. chim. acta, 33, 1966.

Chinard, F. P. (1952). J. biol. Chem. 199, 91.

de Barbieri, A. \& Scevola, M. E. (1955). Bull. Soc. ital. Biol. sper. 31, 688.

Dent, C. E. (1947). Biochem. J. 41, 240.

Dixon, M. \& Webb, E. C. (1958). Enzymes, p. 483. London: Longmans, Green and Co.

Ehrenberg, A. \& Theorell, H. (1955). Acta chem. scand. 9, 1193.

Hayes, J. E. \& Velick, S. F. (1954). J. biol. Chem. $207,225$.

Hirs, C. H. W. (1954). Fed. Proc. 13, 230.

Lange, K. (1956). Hoppe-Seyl. Z. 303, 272.

Leaf, G., Gillies, N. E. \& Pirie, R. (1958). Biochem. J. 69, 605.

Moore, S. \& Stein, W. H. (1948). J. biol. Chem. 176, 367.

Moore, S. \& Stein, W. H. (1951). J. biol. Chem. 192, 663.

Morton, R. K. (1958). Rev. pure appl. Chem. 8, 161.

Nunnikhoven, R. (1958). Biochim. biophys. Acta, 28, 108.

Rees, M. W. (1946). Biochem. J. 40, 632.

Rees, M. W. \& Savage, N. (1958). Cited as personal communication by Dixon, M. \& Webb, E. C. (1958). Enzymes. London: Longmans, Green and Co.

Savage, N. (1957). Biochem. J. 67, 146.

Simmonds, D. H. (1954). Aust. J. biol. Sci. 7, 98.

Simmonds, D. H., Appleby, C. A. \& Morton, R. K. (1957a). Aust. J. Sci. 20, 59.

Simmonds, D. H., Appleby, C. A. \& Morton, R. K. (1957b). Appendix I in Appleby, C. A. Ph.D. Thesis: University of Melbourne.

Simmonds, D. H. \& Wood, K. I. (1954). Analyt. Chem. 26, 1850.

Smith, E. L. \& Stockell, A. (1954). J. biol. Chem. $207,501$.

Smith, E. L., Stockell, A. \& Kimmel, J. R. (1954). J. biol. Chem. 207, 551.

Spies, J. R. \& Chambers, D. C. (1949). Analyt. Chem. 21, 1249. 